\title{
STABILITY OF FERROUS SULFAMATE \\ IN NITRIC ACID SOLUTIONS
}

\section{by}

E. Kenneth Dukes

Richard M. Wallace

\author{
Approved by
}

C. H. Ice, Director

Separations Chemistry and Engineering Section

February 1964

E. I. DU PONT DE NEMOURS \& COMPANY EXPLOSIVES DEPARTMENT - ATOMIC ENERGY DIVISION TECHNICAL DIVISION - SAVANNAH RIVER LABORATORY AIKEN, SOUTH CAROLINA CONTRACT AT $(07-2) \cdot 1$ WITH THE UNITED STATES ATOMIC ENERGY COMMISSION 


\section{DISCLAIMER}

This report was prepared as an account of work sponsored by an agency of the United States Government. Neither the United States Government nor any agency Thereof, nor any of their employees, makes any warranty, express or implied, or assumes any legal liability or responsibility for the accuracy, completeness, or usefulness of any information, apparatus, product, or process disclosed, or represents that its use would not infringe privately owned rights. Reference herein to any specific commercial product, process, or service by trade name, trademark, manufacturer, or otherwise does not necessarily constitute or imply its endorsement, recommendation, or favoring by the United States Government or any agency thereof. The views and opinions of authors expressed herein do not necessarily state or reflect those of the United States Government or any agency thereof. 


\section{DISCLAIMER}

Portions of this document may be illegible in electronic image products. Images are produced from the best available original document. 


\begin{abstract}
The rates of oxidation of ferrous ion in solutions of sulfamic acid and 5.0 to $7.0 \mathrm{M} \mathrm{HNO}_{3}$ were measured at temperatures of 23 to $55^{\circ} \mathrm{C}$. From these rates, an expression, $\log \mathrm{k}=4.56 \log \left[\mathrm{HNO}_{3}\right]-5140\left(1 / \mathrm{T}^{\circ} \mathrm{K}\right)+10.4$, was derived for calculating the rate of oxidation of ferrous ion under these conditions.
\end{abstract}




\section{STABILITY OF FERROUS SULFAMATE \\ IN NITRIC ACID SOLUTIONS}

\section{INTRODUCTION}

Ferrous sulfamate is used to adjust or control the valence states of plutonium and neptunium in nitrate solutions. (1) In some applications a suitable concentration of ferrous sulfamate must be maintained for an extended period during a chemical operation. For such applications a reliable prediction is needed for the rate at which ferrous sulfamate is destroyed in the process solution.

The stability of ferrous sulfamate in specific process solutions has been studied previously. $(2,3)$ The present study was made to provide data for predicting the rate of oxidation of ferrous ion in solutions of sulfamic and nitric acias.

\section{DISCUSSION}

When ferrous sulfamate is used to control valence states in nitric acid solutions, the ferrous ion serves as the reductant, while the sulfamate ion reacts with nitrite to prevent the rapid (autocatalytic) oxidation of ferrous and other ions. However, in the presence of sulfamic acid, nitric acid oxidizes ferrous ion at a measurable rate. (4) The important reactions involved in the oxidation are:

$$
\begin{aligned}
& 2 \mathrm{H}^{+}+\mathrm{HNO}_{3}+2 \mathrm{Fe}^{++} \rightarrow 2 \mathrm{Fe}^{+++}+\mathrm{HNO}_{2}+\mathrm{H}_{2} \mathrm{O} \\
& \mathrm{HNO}_{2}+\mathrm{HOSO}_{2} \mathrm{NH}_{2} \rightarrow \mathrm{H}_{2} \mathrm{SO}_{4}+\mathrm{N}_{2} \mathrm{O}+\mathrm{H}_{2} \\
& \mathrm{H}^{+}+\mathrm{HNO}_{2}+\mathrm{Fe}^{++} \rightarrow \mathrm{Fe}^{+++}+\mathrm{NO}+\mathrm{H}_{2} \mathrm{O} \\
& \mathrm{HNO}_{3}+2 \mathrm{NO}+\mathrm{H}_{2} \mathrm{O} \rightarrow 3 \mathrm{HNO}_{2} \text { (rapid) }
\end{aligned}
$$

At lower temperatures and acid concentrations, oxidation is predominately by Reaction 1, because Reaction 2 reduces the concentration of $\mathrm{HNO}_{2}$ and thereby inhibits Reaction 3 .

The rate of oxidation of ferrous ion was measured as a function of temperature and of the concentrations of nitric acid, ferrous sulfamate, and free sulfamic acid. In the experimental procedure, an aliquot of ferrous sulfamate was 
added to the appropriate solution at the desired temperature, and the concentration of ferrous ion was determined at regular intervals by ceric titration.

The oxidation of ferrous sulfamate in nitric acid solution was first order with respect to the ferrous ion for acid concentrations of 5.0 to $8.0 \mathrm{M}$ and temperatures of 23 to $42^{\circ} \mathrm{C}$. As shown in Figure 1 , the first-order rate constant was about the same for $0.05 \mathrm{M}$ and $0.15 \mathrm{M}$ ferrous sulfamate in $8.0 \mathrm{M} \mathrm{HNO}_{3}$ at $42^{\circ} \mathrm{C}$. The oxidation at $55^{\circ} \mathrm{C}$ was first order for 5 to $7 \mathrm{M} \mathrm{HNO}_{3}$, but for $8 \mathrm{M} \mathrm{HNO}_{3}$ at this temperature, the rate increased with time. However, as shown in Figure 2, the addition of sulfamic acid to increase the ratio of sulfamate to ferrous restored the oxidation to a first-order rate.

Data showing the effect of nitric acid concentration on the oxidation rates at 30 and $34^{\circ} \mathrm{C}$ are presented in Figure 3 . Average data for temperatures of 23 to $42^{\circ} \mathrm{C}$ gave a rate dependent on the 4.56 power of the acid concentration.

The effect of temperature on the oxidation rate is shown in Figure 4. These data were used to calculate an apparent activation energy of $23.5 \mathrm{kcal} / \mathrm{mol}$ for the reaction.

Results from 23 rate experiments were treated by the method of least squares, and the oxidation of ferrous ion by nitric acid was fitted by the expression

$$
\log k=4.56 \log \left[\mathrm{HNO}_{3}\right]-5140\left(\frac{1}{\mathrm{~T}^{\circ} \mathrm{K}}\right)+10.4
$$

where $k$ is the first-order rate constant for the oxidation of ferrous ion. The agreement between the calculated and experimental rate constants is shown in Table $I$. The oxidation of ferrous sulfamate in $8 \mathrm{M} \mathrm{HNO}_{3}$ at $55^{\circ} \mathrm{C}$ does not fit the empirical expression. However, under these conditions the oxidation is so rapid ( $t_{\frac{1}{2}}=6$ minutes), that a prediction of the rate is unnecessary. 


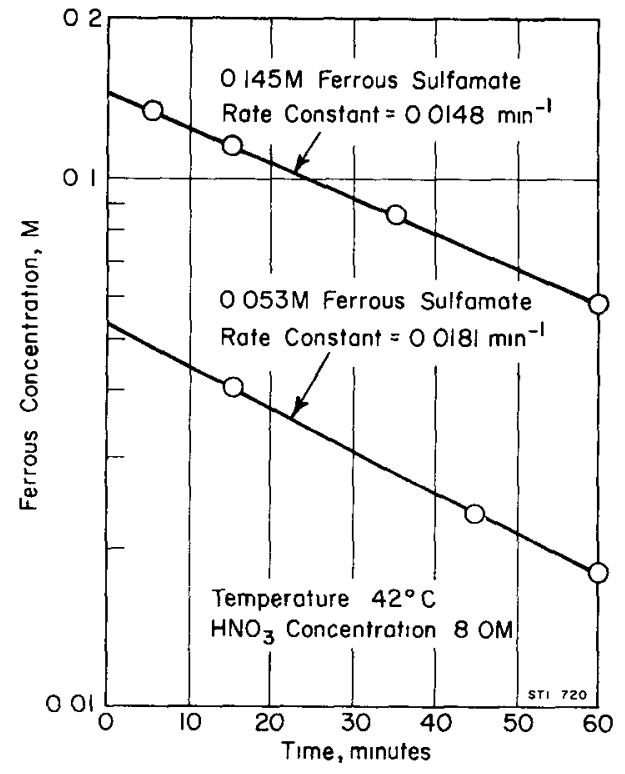

FIG. 1 EFFECT OF CONCENTRATION OF FERROUS SULFAMATE ON RATE OF OXIDATION OF FERROUS ION

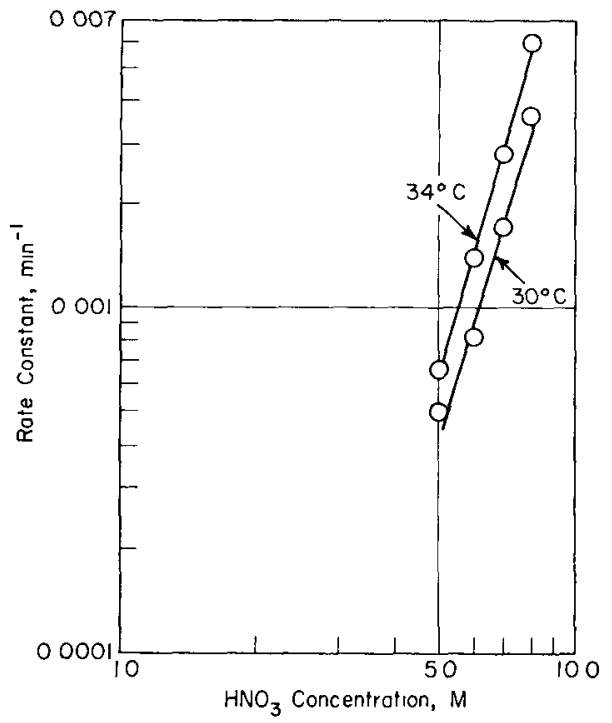

FIG. 3 EFFECT OF CONCENTRATION OF NITRIC ACID ON RATE OF OXIDATION OF FERROUS ION

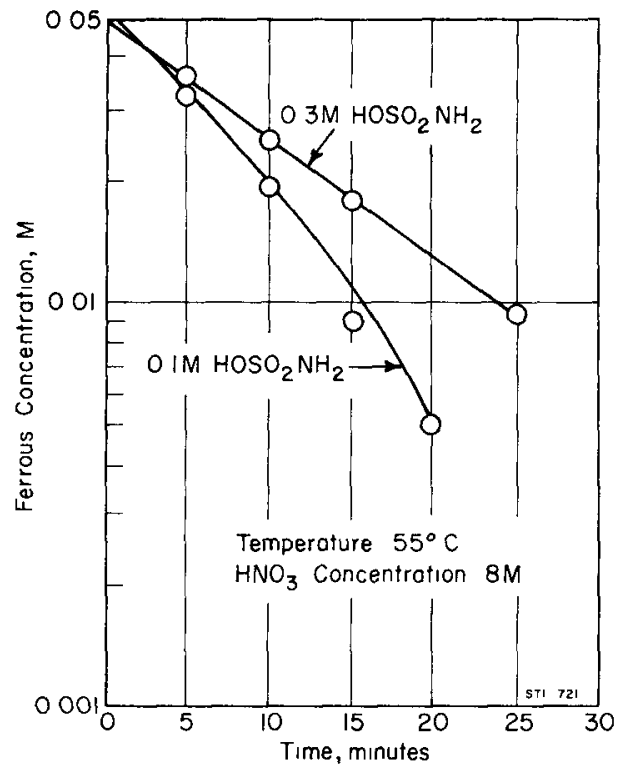

FIG. 2 EFFECT OF CONCENTRATION OF SULFAMIC ACID ON RATE OF OXIDATION OF FERROUS ION

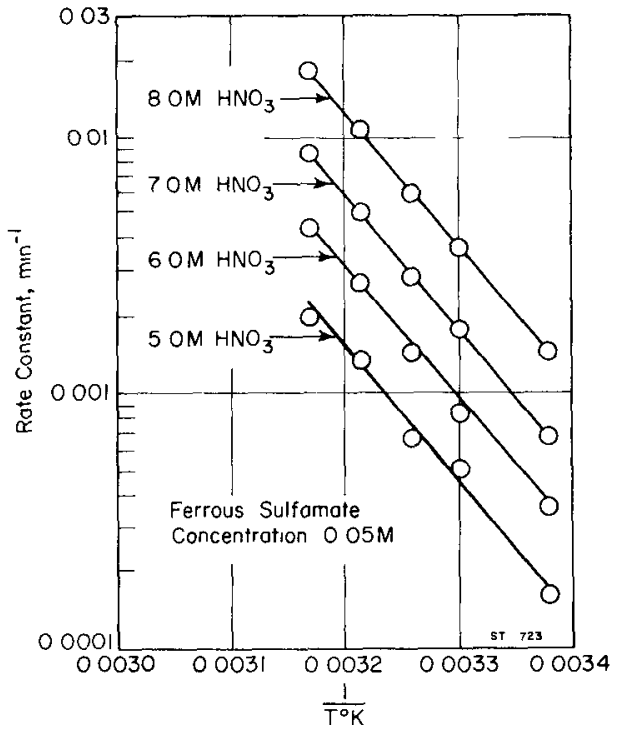

FIG. 4 EFFECT OF TEMPERATURE ON RATE OF OXIDATION OF FERROUS ION 
Experimental and Calculated Rates of Oxidation of Ferrous Ion in Solutions of Sulfamic and Nitric Acids

\begin{tabular}{|c|c|c|c|c|}
\hline \multirow{2}{*}{$\begin{array}{c}\mathrm{HNO}_{3} \text { Conc, } \\
\mathrm{M} \\
\end{array}$} & \multirow{2}{*}{$\begin{array}{r}\text { Temp, } \\
{ }^{\circ} \mathrm{C} \\
\end{array}$} & \multicolumn{2}{|c|}{ Oxidation Rate, $\min ^{-1}$} & \multirow{2}{*}{$\begin{array}{c}\text { Difference, } \\
\%\end{array}$} \\
\hline & & Experimental & Calculated & \\
\hline 5.0 & 23 & 0.00016 & 0.00016 & - \\
\hline 6.0 & 23 & 0.00035 & 0.00037 & 5.4 \\
\hline 7.0 & 23 & 0.00066 & 0.00074 & 10.8 \\
\hline 8.0 & 23 & 0.0014 & 0.0014 & - \\
\hline 5.0 & 30 & 0.00049 & 0.00041 & 22.0 \\
\hline 6.0 & 30 & 0.00081 & 0.00095 & 14.7 \\
\hline 7.0 & 30 & 0.0017 & 0.0019 & 10.5 \\
\hline 8.0 & 30 & 0.0036 & 0.0035 & 2.9 \\
\hline 5.0 & 34 & 0.00065 & 0.00066 & 1.5 \\
\hline 6.0 & 34 & 0.0014 & 0.0015 & 6.7 \\
\hline 7.0 & 34 & 0.0028 & 0.0031 & 9.7 \\
\hline 8.0 & 34 & 0.0059 & 0.0056 & 5.4 \\
\hline 5.0 & 38 & 0.0013 & 0.0011 & 18.2 \\
\hline 6.0 & 38 & 0.0026 & 0.0024 & 8.3 \\
\hline 7.0 & 38 & 0.0049 & 0.0049 & - \\
\hline 8.0 & 38 & 0.0105 & 0.0091 & 15.4 \\
\hline 5.0 & 42 & 0.0019 & 0.0019 & - \\
\hline 6.0 & 42 & 0.0043 & 0.0044 & 2.3 \\
\hline 7.0 & 42 & 0.0084 & 0.0089 & 5.6 \\
\hline 8.0 & 42 & 0.0181 & 0.0160 & 13.1 \\
\hline 5.0 & 55 & 0.0055 & 0.0079 & 30.3 \\
\hline 6.0 & 55 & 0.0196 & 0.0180 & 8.9 \\
\hline 7.0 & 55 & 0.0410 & 0.0370 & 10.8 \\
\hline
\end{tabular}




\section{BIBLIOGRAPHY}

1. Burney, G. A. Separation of Neptunium and Plutonium by Anion Exchange. E. I. du Pont de Nemours \& Co., Savannah River Laboratory, Aiken, S. C. USAEC Report DP-689 (1962) (declassified July 18, 1963).

2. Tober, F. W. and E. R. Russell. Concentration of Plutonium by Cation Exchange-Stabilization of Pu(III) in Nitric Acid. E. I. du Pont de Nemours \& Co., Savannah River Laboratory, Aiken, S. C. USAEC Report DP-349 (1960) (declassified March 1, 1962).

3. Clagett, F. Ferrous Sulfamate Stability in the RA System. Hanford Works, Richland, Wash. USAEC Report $\overline{H W}-17698$ (1950).

4. Dukes, E. K. and R. M. Wallace. Formation of Hydrazoic Acid from Hydrazine in Nitric Acid Solutions. E. I. du Pont de Nemours \& Co., Savannah River Laboratory, Aiken, S. C. USAEC Report DP-728 (1962). 